\title{
Richness, composition and trophic groups of an avian community in the Pernambuco Endemism Centre, Alagoas, Brazil
}

\author{
GUILHERME S. TOLEDO-LIMA ${ }^{1}$, PHOEVE MACARIO ${ }^{1}$, RACHEL M. DE LYRA-NEVES ${ }^{2}$, \\ BRUNO P. TEIXEIRA ${ }^{1}$, LUIZ A.F. DE LIMA ${ }^{3}$, GABRIEL O.S. SUGLIANO ${ }^{1 *}$ \\ and WALLACE R. TELINO-JÚNIOR ${ }^{2}$ \\ ${ }^{1}$ Laboratório de Ornitologia e Taxidermia, Museu de História Natural, Universidade Federal de Alagoas, \\ Av. Aristeu de Andrade, 452, 57051-090 Maceió, AL, Brasil \\ ${ }^{2}$ Laboratório de Ensino de Zoologia, Universidade Federal Rural de Pernambuco, Unidade Acadêmica de Garanhuns, \\ Av. Bom Pastor, s/n, 55292-270 Garanhuns, PE, Brasil \\ ${ }^{3}$ Setor de Dermatologia, Universidade Estadual de Ciências da Saúde de Alagoas, \\ Rua Doutor Jorge de Lima, 113, 57010-300 Maceió, AL, Brasil
}

Manuscript received on April 8, 2013; accepted for publication on September 9, 2013

\begin{abstract}
In northeastern Brazil, the reduction of the natural forest cover to a series of small, isolated fragments has had negative consequences for the local avian fauna, in particular, a loss of the more specialized species, while the populations of some generalists have tended to increase. The present study focuses on the composition and trophic groups of a bird community on a farm in the northeastern Brazilian state of Alagoas. Monthly surveys were conducted between November 2008 and October 2009, based on mistnetting and systematic observations. Overall, 112 species were recorded, of which 76 were associated with the two forest fragments surveyed, while all the others were observed exclusively in the surrounding matrix of pasture and orchards. The bird community presented a predominance of insectivorous species, followed by omnivores. However, specialized trunk-creeping and understory insectivores accounted for only around $15 \%$ of the species in this feeding category. The reduced diversity of other guilds and species with more specialized diets, and the complete absence of sensitive species such as large parrots and raptors, reflects the severe fragmentation and degradation of the local forests, which has greatly reduced the availability of dietary resources and breeding sites.
\end{abstract}

Key words: Atlantic Forest, birds, Northeastern Brazil, trophic groups.

\section{INTRODUCTION}

The Atlantic Forest is distributed among 17 states in eastern Brazil, encompassing a wide latitudinal amplitude, and a range of climatic and edaphic conditions (Moura 2006, Ribeiro et al. 2009). The

Correspondence to: Guilherme Santos Toledo-Lima

E-mail: toledolimagui@gmail.com

*in memoriam northernmost sector of the Atlantic Forest, in the Brazilian Northeast, is the most threatened part of the biome, with only $2 \%$ of its original forest cover remaining. The colonization of this region and its long history of anthropogenic impact have resulted in the loss of much of its forest cover (Teixeira 1985, Silva and Tabarelli 2000, Menezes et al. 2004, Araujo and Moura 2011). The reduction of 
the original forest cover to a series of small, isolated fragments has had negative consequences for the local bird fauna, in particular the loss of the more specialized species, with a concomitant increase in the proportion of more opportunistic species, such as omnivores and generalized insectivores (D’Angelo-Neto et al. 1998, Sodhi et al. 2011).

Understanding the trophic structure of a bird assemblage - in particular the presence or absence of specific guilds - may offer important insights into the conservation status of a given area. This information provides important guidelines for conservation and management projects in ecosystems such as those of the Atlantic Forest (Motta-Junior 1990, Donatelli et al. 2004, Rodrigues et al. 2007). The ecological diversity of birds, their sensitivity to impacts, and the wealth of data, all combine to render these animals extremely useful as bio-indicators of natural or anthropogenic impacts (Verner 1981, Reynaud and Thioulouse 2000, Primack and Rodrigues 2001).

Some 434 known bird taxa are found in the Pernambuco Endemism Centre, as the Atlantic Forest north of the São Francisco River is known (Roda 2006), of which, 38 are endemic (Silveira et al. 2003a), 45 are classified as threatened (IUCN 2008, MMA 2008), and one - the Alagoas Curassow, Pauxi mitu (Silveira and Straube 2008) - is extinct in the wild. While a number of surveys have been conducted in this region (Silveira et al. 2003a, Lyra-Neves et al. 2004, Barnett et al. 2005, Roda 2006, Farias et al. 2007), few data are available on the trophic structure of the local communities (Telino-Júnior et al. 2005, Rodrigues et al. 2007).

This lack of data is most emphatic in the case of the Brazilian state of Alagoas. In the present study, data are provided on the composition and trophic groups of an Atlantic Forest bird community from this state, with the main aim of obtaining new insights into the ecological processes that underpin the diversity of these animals in the region.

\section{MATERIALS AND METHODS}

The study was conducted at the Fazenda Santa Fé, located in the municipality of Tanque d'Arca in central Alagoas, northeastern Brazil. Tanque d'Arca covers an area of $129.5 \mathrm{~km}^{2}$, of which, $30.7 \mathrm{~km}^{2}$ is covered with its original vegetation (Menezes 2010). The climate is dry subhumid and megathermic with a pronounced hydrological deficit in the austral summer months (DecemberFebruary). Average temperatures range between around $21.6^{\circ} \mathrm{C}$ in July and August, to $26.3^{\circ} \mathrm{C}$ in January, while total annual precipitation is generally between 900 and $1000 \mathrm{~mm}$, concentrated mainly in the austral autumn and winter months, i.e. March through August (Lima 2012).

This rural property encompasses a number of small forest fragments isolated by a matrix of pasture. The two largest fragments have been transformed into private natural heritage reserves ("RPPNs"), known as Santa Fé (area 1) and Cachoeira (area 2), located approximately $600 \mathrm{~m}$ from one another. Both areas are covered in semideciduous forest, adapted to the rainy/dry cycle of the local climate (Veloso 1992, Assis 2000).

The Santa Fé reserve (09³1'16” S, 36²6’42” W) covers an area of 18 ha and is located at $370 \mathrm{~m}$ above sea level, while Cachoeira (09 $32^{\prime} 02^{\prime}$ S , $36^{\circ} 26^{\prime} 45^{\prime \prime} \mathrm{W}$ ) covers 35 ha at $320 \mathrm{~m}$. Both areas are characterized by patches of secondary forest, and have been protected from selective logging and hunting by the owner of the property for nearly 20 years.

The study was conducted between November 2008 and October 2009, with monthly excursions of two consecutive days, and a total of 12 samples. The bird fauna of each study area was surveyed by the simple list method (Ribon 2010), in which existing trails within the pasture, forest, and mixed habitats were walked at 05:00-10:00 $\mathrm{h}$ and 15:0018:00 h. Visual observations and sound recordings were logged in a field notebook, over a total of 192 hours of monitoring. Observations were 
conducted using a pair of $7 \times 35$ binoculars, while vocalizations were recorded with a digital recorder and unidirectional microphone.

In addition to observations, birds were captured using eight mist-nets (12 m x $2.5 \mathrm{~m}$ ) installed in pairs along transects both within and at the edges of the reserves. The nets were set in the mornings, from $06: 00 \mathrm{~h}$ to $11: 00 \mathrm{~h}$, and afternoons, between 15:00 $\mathrm{h}$ and 17:00 h, with a total effort of 40,320 h.m ${ }^{2}$ (Straube and Bianconi 2002). The captured birds were marked with aluminum leg bands provided by CEMAVE/ICMBio and had their biometric data collected using a millimeter-scale steel ruler, calipers, and dynamometer.

Bird species were identified using field guides, as well as consultations with taxonomic specialists and archives in sound libraries for comparison with the vocalizations recorded in the field. The popular and scientific nomenclature follows the scheme of the Brazilian Ornithological Records Committee (CBRO 2011). Observed species richness was represented using a rarefaction curve produced by the EstimateS 8.2 software (Colwell 2011), and estimates of total richness were obtained using the Chao2 and Jackknife 1 estimators, nonparametric methods recommended by H.F.P. de Araujo (unpublished data) for the analysis of bird faunas.

All species were assigned to one of the following trophic categories-carnivore, detritivore, frugivore, granivore, insectivore, nectarivore, omnivore or piscivore. This classification was based on field observations and on available literature (Moojen et al. 1941, Motta-Junior 1990, Sick 1997, Telino-Júnior et al. 2005).

The relative frequency of each species was calculated according to Dajoz (1983), that is, the proportion of samples in which the species was recorded. Naka et al. (2002) classified the frequencies as: common, $\geq 75 \%$; fairly common, $50 \%-74 \%$; uncommon, $25 \%-49 \%$; and rare, $\leq 24 \%$.

Jaccard's similarity index (Krebs 1989) was used to compare the two bird communities. This index divides the number of shared species by the sum of the species recorded at the two sites.

\section{RESULTS}

A total of 112 bird species were identified during the present study, representing 39 families in 18 orders. The family with the largest number of species was the Tyrannidae (13.4\% of the total), followed by Thraupidae $(9.8 \%)$ and Trochilidae (6.3\%). However, only $76(67.9 \%)$ of these species were recorded in the forest fragments (areas 1 and 2), with the other 36 being observed in the surrounding matrix (pasture) and other habitats, such as orchards and flower plantations. Area 1 presented the highest species richness, with a total of 66 species, while 59 were recorded in area 2 , and there was $64 \%$ similarity between the two sites.

The number of species recorded per month ranged from 24 to 60 , with the lowest numbers being recorded during the rainy season (MarchJuly) and the highest in the dry season. The species rarefaction curve had not reached the asymptote by the end of the survey period, indicating that the total number of species occurring in the study area was underestimated during the surveys. This conclusion was reinforced by the Chao2 and Jackknife 1 estimators, which indicated mean $( \pm \mathrm{SD})$ richness at approximately $118 \pm 6.4$ and $125 \pm 3.4$ species, respectively (Figure 1).

Seven of the species recorded in the present study are endemic to Brazil, according to the CBRO (2011): Pygmy Nightjar (Hydropsalis hirundinacea), Tawny Piculet (Picumnus fulvescens), Gray-eyed Greenlet (Hylophilus amaurocephalus), Long-billed Wren (Cantorchilus longirostris), Seven-colored Tanager (Tangara fastuosa), Red-cowled Cardinal (Paroaria dominicana), and White-Throated Seedeater (Sporophila albogularis). Of these, the Tawny Piculet and Seven-colored Tanager are classified as threatened species by the IUCN (2008) and MMA (2008). 


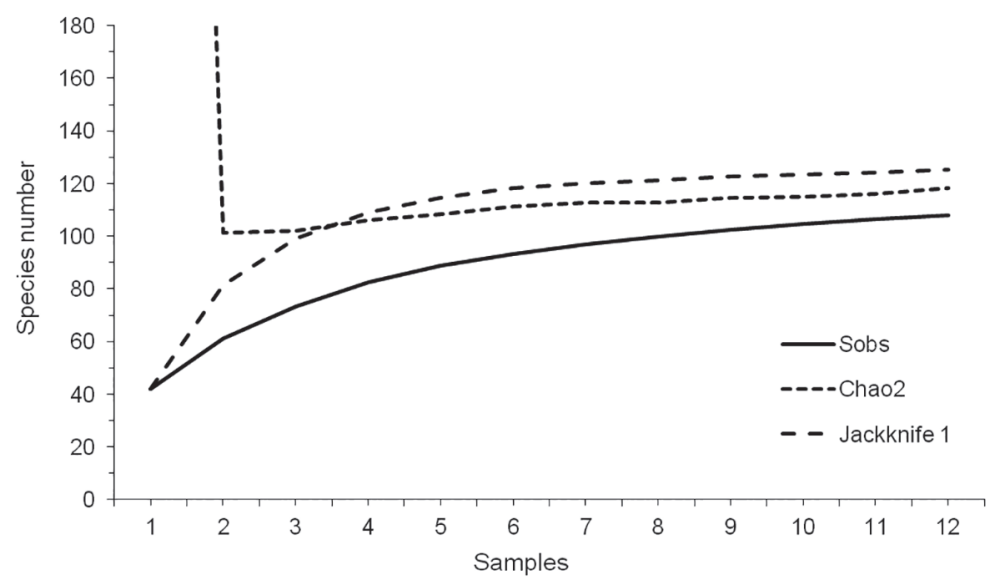

Figure 1 - Species rarefaction curve (Sobs) and estimated richness (Chao2 and Jackknife 1) of the bird community in Fazenda Santa Fé, Tanque d'Arca - AL.

Three species, the Scaled Dove (Columbina squammata), Saffron Finch (Sicalis flaveola) and Red-cowled Cardinal were recorded regularly throughout the study period, although as individuals of these species were being released into the wild at both sites by the owner of the property and other local residents, their frequencies were not included in the analyses. The full species list and their relative frequencies are presented in Appendix.

The trophic structure of the bird community at the study site was characterized by a predominance of insectivorous species, followed by omnivores (Table I). These categories are well represented by tyrannids and thraupids, such as the Tropical Kingbird (Tyrannus melancholicus), Gray Elaenia (Myiopagis caniceps), Sayaca Tanager (Tangara sayaca), and Burnished-buff Tanager (Tangara cayana), which were common or fairly common in the study area. However, specialized insectivores, such as those that forage on tree trunks or in the understory (Picidae, Dendrocolaptidae, and Thamnophilidae) were rare in the forested areas.

The carnivores (Accipitridae, Falconidae, Strigidae, and Tytonidae) were the third richest species, especially those adapted for foraging in open areas and at forest edges. The dispersal potential of these raptor species probably determined an increased likelihood of encounters within the study area,
TABLE I

Trophic groups recorded at Fazenda Santa Fé, Tanque d'Arca, AL.

\begin{tabular}{ccc}
\hline \multirow{2}{*}{ Feeding Habits } & \multicolumn{2}{c}{ Proportion of species } \\
\cline { 2 - 3 } & $\mathbf{N}$ & $\mathbf{( \% )}$ \\
\hline Carnivore & 9 & 8 \\
Detritivore & 3 & 2.7 \\
Frugivore & 6 & 5.4 \\
Granivore & 7 & 6.3 \\
Insectivore & 47 & 42 \\
Nectarivore & 8 & 7.1 \\
Omnivore & 27 & 24.1 \\
Piscivore & 5 & 4.5 \\
\hline Total & $\mathbf{1 1 2}$ & $\mathbf{1 0 0}$ \\
\hline
\end{tabular}

in particular diurnal species, such as Roadside Hawk (Rupornis magnirostris), Southern Caracara (Caracara plancus) and Yellow-headed Caracara (Milvago chimachima).

The frugivores were represented mainly by small passerines such as White-bearded Manakin (Manacus manacus), which were restricted to areas of secondary vegetation or shrubby growth, and the endangered Seven-colored Tanager and Violaceous Euphonia (Euphonia violacea), which were observed typically in orchards. Larger frugivores, such as toucans, cotingas, and bellbirds, were absent, although the Speckled Chachalaca (Ortalis guttata) and Red-shouldered Macaw (Diopsittaca nobilis) were recorded in both forest reserves. 


\section{DISCUSSION}

The number of species recorded in the present study was relatively low in comparison to previous surveys, especially those of forest communities in similar habitats. For example, Lobo-Araújo et al. (2013) inventoried the bird fauna in three forest fragments at a site located approximately $40 \mathrm{~km}$ from Tanque d'Arca, recording 91 species, in contrast to the 76 found in the present study. This discrepancy is probably due to the relatively small size of the forest reserves surveyed in the present study, and also their isolation from potential source areas. Silveira et al. (2003a) recorded even lower species richness in similar dry forests in Alagoas (24-53 species), although in this case, sampling efforts were greatly reduced - 17 hours - in comparison to the present study $\left(40,320\right.$ h.m $\mathrm{m}^{2}$ of mistnetting and $192 \mathrm{~h}$ of monitoring) and that of LoboAraújo et al. (2013), based on 160 hours.

While they were relatively close to one another, the two reserves differed considerably in terms of species richness and composition. This may be related to the fact that the two fragments have suffered distinct patterns of anthropogenic impact. In particular, area 2 is adjacent to an urban area, which facilitates encroachment by local residents for the collection of firewood, selective logging, and the hunting and trapping of birds. Area 1 is not only further away from the urban area, but adjacent to the farmhouse, which probably contributes to the prevention of, or at least the limitation of activities such as hunting and logging. D'Angelo-Neto et al. (1998) identified similar factors determining the reduced similarity of the bird communities of adjacent forests. An additional factor in the present study may have been the inaccessibility of parts of area 2, which could not be surveyed adequately, and may have contained a number of less conspicuous species, that were not recorded during the study.

During the breeding (dry) season, many species may become more conspicuous due to their more intense vocalizations, whereas they tend to become less active (and thus more cryptic) during the rainy season (Lyra-Neves et al. 2004). This seasonal variation in detectability, together with the regional migrations observed in some species, such as the Black-throated Mango (Anthracothorax nigricollis) and Ruby-topaz Hummingbird, Chrysolampis mosquitus (Ruschi 1982, Sick 1997) contributed to the observed fluctuations in species richness in the study area. In a semi-deciduous forest in southeastern Brazil, Aleixo and Vielliard (1995) also recorded a larger number of species in the dry season, with the highest species richness being recorded in September and the lowest in March, as found in the present study.

Tawny Piculet, Red-cowled Cardinal and Whitethroated Seedeater are endemic to the Caatinga, and are rarely observed in the adjacent biomes (Pacheco 2004). The presence of these species in the study area may thus be related to the fact that it was originally located within the transition zone between the Atlantic Forest and the semi-arid Caatinga. Recent anthropogenic impacts have established a mosaic of habitats, in which the bird communities typical of the two biomes may coexist. An additional potential factor may be the local tradition of maintaining songbirds, such as the White-throated Seedeater and Red-cowled Cardinal, in captivity. That may have increased species ranges through illegal trafficking and uncontrolled releases, since these species are able to adapt to anthropogenic habitats (Olmos et al. 2005, Araujo and Rodrigues 2011, Araujo et al. 2012).

The Seven-colored Tanager is endemic to the Pernambuco Endemism Centre and is classified as vulnerable by the IUCN (2008) and MMA (2008). In the present study, the species was recorded mainly in the dry season, when young individuals were observed feeding on mango (Mangifera indica) and cashew fruits (Anacardium occidentale) in February. The species has also been recorded in Alagoas by Silveira et al. (2003a) and Lobo-Araújo et al. (2013). Studying 17 forest fragments in the state, Silveira et al. (2003b) did 
not observe this species in the dry southern forests, where the reduced abundance of plants of the Melastomataceae family may limit the occurrence of this tanager. In the present study, the species was only observed in orchards and open woodland, rich in epiphytic bromeliads, and never in the forests, which lacked Melastomataceae plants. Further data are required, however, in order to confirm the species' habitat preferences and requirements.

The predominance of insectivorous and omnivorous species is consistent with the results of Willis (1979), Motta-Junior (1990), Aleixo (1999), Anjos (2001), Telino-Júnior et al. (2005), and Catian et al. (2011). While insectivores have access to a relatively stable resource throughout the year, omnivores are able to adapt to prevailing conditions and resource availability (Scherer et al. 2005). These groups contain many tyrannids and thraupids, which tend to be relatively tolerant of anthropogenic impacts and seasonal fluctuations in the abundance of resources without resorting to migration.

However, the insectivores specialized in foraging on trunks, branches and in the understory accounted for only approximately $15 \%$ of this feeding category. These species may become locally extinct not only through the loss of forest habitat, but also due to the disturbance of the vegetation. The degree of isolation of a forest fragment and the characteristics of the matrix that separates it from possible source areas are also factors limiting recolonization by these guilds (Aleixo and Vielliard 1995, Stouffer and Bierregaard 1995). It thus seems likely that species such as White-shouldered Antshrike (Thamnophilus aethiops), White-backed Fire-eye (Pyriglena leuconota) and Plain Antvireo (Dysithamnus mentalis), which were not recorded during the present study, are locally extinct. Trunkcreeping insectivores were represented by the Little Woodpecker (Veniliornis passerinus) Olivaceous Woodcreeper (Sittasomus griseicapillus), Straightbilled Woodcreeper (Dendroplex picus) and Tawny Piculet, of which the latter two species are relatively common and habitat generalists, being found in environments ranging from dense forest to open woodland. Other members of this guild known to occur in forest fragments in Alagoas and Pernambuco, such as Plain-brown Woodcreeper Dendrocincla fuliginosa and Buff-throated Woodcreeper Xiphorhynchus guttatus, were all absent from the study area.

Carnivores were represented predominantly by widely-distributed species such as the Tropical Screech-Owl (Megascops choliba), Roadside Hawk, Southern Caracara and Yellow-headed Caracara, which were recorded frequently throughout the study area, but especially in the pasture and forest edge. The latter three species have been classified by Azevedo et al. (2003), Loures-Ribeiro and Anjos (2006) and Carvalho and Marini (2007) as habitat generalists, which may even be relatively common in anthropogenically-impacted habitats, in particular the Roadside Hawk and the Southern Caracara (Carvalho and Marini 2007). The tolerance of these species to human impact, combined with their ample resource base, ranging from invertebrates and small vertebrates to carrion (livestock carcasses), may contribute to their abundance within the study area (Moojen et al. 1941, Sick 1997, Carvalho and Marini 2007).

Of the least diverse feeding groups, the frugivores were represented by only six species, most of which were small passerines, such as the Violaceous Euphonia and Seven-colored Tanager. The local orchards were important feeding sites for these species, where fruiting trees like $M$. indica and $A$. occidentale were visited frequently during the dry season months. Larger, less adaptable frugivores, such as parrots, toucans, and cotingas, were absent from the study area. Forest-dwelling frugivores generally depend on relatively large areas of habitat in order to guarantee a year-round supply of food, and tend to occur at low densities in small fragments, travelling long distances to find fruiting trees (D'Angelo-Neto et al. 1998, TelinoJúnior et al. 2005). Many of these frugivores also 
require specific resources such as cavities in large trees for nesting (Silveira et al. 2003a), which tend to be scarce in disturbed forests, such as those of the present study area, which have suffered selective logging in the past.

The frugivores recorded in the present study included the Speckled Chachalaca and Red-shouldered Macaw, which, while being rare overall, were observed in small bands. The Speckled Chachalaca is a habitat generalist and appears to be the cracid best adapted to the anthropogenic landscape of present-day northeastern Brazil (del Hoyo 1994, Parker III et al. 1996, Silveira et al. 2003a). During the dry season, groups of five to nine Red-shouldered Macaws were observed moving between palms (Arecaceae) in the pasture and also in the forest canopy. This species may still be observed flying between remnant forests in the Alagoas state capital, Maceió, and surrounding areas, and it is in fact able to inhabit agricultural environments, especially where palm trees are found (Collar 1997). Clearly, then, the species' tolerance of human interference may guarantee its long-term survival in the region.

A large proportion (32\%) of all the species recorded was observed exclusively in anthropogenic habitats, indicating reduced sensitivity to habitat disturbance in these species. The present-day composition of the bird fauna in the forest fragments reflects the impacts they have suffered in the past. The reduced abundance of some more specialized species, such as understory insectivores, and the complete absence of large raptors, parrots, and bellbirds, appear to reflect the severe degradation of the local forests, which has greatly reduced the diversity and availability of dietary resources and, for some species, breeding sites.

In this context, the Tawny Piculet and Sevencolored Tanager, species considered by some authors as being intolerant, seem to have coped with local impacts, and appear to be breeding within the study area. As suggested above, further data on the ecology of these and some other species will be required in order to fully understand their habitat preferences and feeding behavior.

The establishment of the forest reserves surveyed in the present study was of vital importance for the survival of the remnant bird communities, and will provide a sound platform for the development of long-term conservation measures, such as the establishment of forest corridors and the controlled reintroduction of species that have become locally extinct. The creation of protected areas on private properties should be encouraged throughout the region, given the importance of these fragments for the survival of remaining forests and the protection of their natural resources, including their bird populations.

\section{ACKNOWLEDGMENTS}

We wish to thank Dr. Luiz Alberto F. de Lima and Ms. Maria Celia M. Lima for permitting the study on their property and for logistical support. We are also grateful to the staff of Fazenda Santa Fé, Mr. Agripino de Oliveira, João dos Santos and Gilda dos Santos for their attention and support during fieldwork, and our friends from the Federal University of Alagoas, Lahert W. Lobo-Araújo, Edivaldo B. S. Filho and Jackson F. Lima, for their support in the field. The Centro Nacional de Pesquisa para Conservação das Aves Silvestres (CEMAVE/ICMBio) supplied the aluminum leg bands. We especially thank Dr. Stephen F. Ferrari for assistance in improving the English manuscript, and the valuable suggestions of the editor and four anonymous reviewers. Finally, we would like to dedicate this study to our great friend and colleague Gabriel Omar Skuk Sugliano (in memoriam) for his invaluable inspiration and guidance.

\section{RESUMO}

No Nordeste do Brasil, a redução da cobertura florestal original a pequenos fragmentos isolados tem trazido 
consequências negativas para a avifauna local, em particular, uma perda de espécies mais especializadas e o aumento populacional de algumas espécies generalistas. O presente estudo foca na composição e nos grupos tróficos de uma comunidade de aves de uma propriedade rural em Alagoas, nordeste do Brasil. Amostragens mensais foram realizadas entre novembro de 2008 e outubro de 2009, através de capturas com redes-deneblina e observações de campo. De forma geral, foram identificadas 112 espécies, das quais 76 estiveram associadas aos dois fragmentos florestais estudados, com as demais ocorrendo apenas na matriz de pasto e pomares. A avifauna da área de estudo demonstrou um predomínio de espécies insetívoras seguidas por onívoras. No entanto, insetívoros especialistas como os forrageadores de troncos e de subosque, corresponderam a apenas $\sim 15 \%$ dos insetívoros como um todo. A baixa diversidade de algumas guildas e espécies com dietas mais específicas e a total ausência de outras espécies sensíveis, tais como grandes rapineiros e papagaios, é reflexo da fragmentação acentuada e degradação das florestas locais, o que reduziu a disponibilidade de recursos alimentares e eliminou seus sítios reprodutivos.

Palavras-chave: Floresta Atlântica, aves, Nordeste do Brasil, grupos tróficos.

\section{REFERENCES}

ALEIXO A. 1999. Effects of selective logging on a bird community in the Brazilian Atlantic Forest. Condor 101: 537-548.

AleiXo A AND VIELLIARD JME. 1995. Composição e dinâmica da avifauna da Mata de Santa Genebra, Campinas, São Paulo, Brasil. Rev Bras Zool 12: 493-511.

ANJos L Dos. 2001. Bird communities in five Atlantic Forest fragments in southern Brazil. Orn Neotr 12: 11-27.

ARAUJo HFP DE AND RodriguES RC. 2011. Birds from open environments in the Caatinga from state of Alagoas, northeastern Brazil. Zoologia 28: 629-640.

ARAujo HFP DE, VieIRA-Filho AH, CAVAlCANTI TA AND BARBOSA MR DE V. 2012. As aves e os ambientes em que elas ocorrem em uma reserva particular no Cariri paraibano, nordeste do Brasil. Rev Bras Ornitol 20: 365-377.

ARAujo LM AND MoURA FBP. 2011. Bioethanol's dirty footprint in Brazil. Nature 469: 299.

ASSIS JS DE. 2000. Biogeografia e conservação da biodiversidade - projeções para Alagoas. Alagoas: Edições Catavento, $200 \mathrm{p}$.
Azevedo MAG, Machado DA and Albuquerque JLB. 2003. Aves de rapina na Ilha de Santa Catarina, SC: composição, frequência de ocorrência, uso de habitat e conservação. Ararajuba 11: 75-81.

BARNETT JM, CARLOS CJ AND RODA SA. 2005. Renewed hope for the threatened avian endemics of northeastern Brazil. Biodivers Conserv 14: 2265-2274.

CARVALHO CEA AND MARINI MÂ. 2007. Distribution patterns of diurnal raptors in open and forested habitats in southeastern Brazil and the effects of urbanization. Bird Conserv Int 17: 367-380.

CATIAN G, FERnANDES WD AND ARANDA R. 2011. Estrutura trófica de aves diurnas no campus da Universidade Federal da Grande Dourados, MS. Rev Bras Ornitol 19: 439-446.

CBRO. 2011. Listas das Aves do Brasil. São Paulo: Comitê Brasileiro de Registros Ornitológicos, 37 p.

Collar NJ. 1997. Family Psittacidae (parrots). In: DEL HOYO JA ET AL. (Eds), Handbook of the birds of the world, Volume 4: Sandgrouse to Cuckoos, Barcelona: Lynx Edicions, Barcelona, Spain, p. 280-477.

COLWELL RK. 2011. EstimateS, Version 8.2: Statistical Estimation of Species Richness and Shared Species from Samples (Software and User's Guide).

DAJOZ R. 1983. Ecologia Geral. Petrópolis: Vozes, 472 p.

D’Angelo Neto S, Venturini N, Oliveira-Filho AT DE AND Costa FAF. 1998. Avifauna de quatro fisionomias florestais de pequeno tamanho (5-8 ha) no Campus da UFLA. Rev Bras Biol 58: 463-472.

Del Hoyo J. 1994. Family Cracidae (chachalacas, guans and curassows). In: DEL HOYO JA ET AL. (Eds), Handbook of the birds of the world, Volume 2: New World Vultures to Guineafowl, Barcelona: Lynx Edicions, Barcelona, Spain, p. 310-363.

Donatelli RJ, Costa TVV DA AND Ferreira CD. 2004. Dinâmica da avifauna em fragmento de mata na Fazenda Rio Claro, Lençóis Paulista, São Paulo, Brasil. Rev Bras Zool 21: 97-114.

FARIAS GB, ALVES ÂGC AND SILVA ACBL. 2007. Riqueza de aves em cinco fragmentos de Floresta Atlântica na Zona da Mata Norte de Pernambuco, Brasil. Biotemas 20: 111-122.

IUCN. 2008. IUCN red list of threatened Species. Available on http://www.redlist.org. (Consulted on 14 July 2013).

KREBS CJ. 1989. Ecological Methodology. New York: Harper and Row Publishers, $654 \mathrm{p}$.

LIMA RCA. 2012. Tanque d'Arca - No caminho dos tropeiros. In: SIMÕES L (Coord), Enciclopédia Municípios de Alagoas, Maceió: Instituto Arnon de Mello, Alagoas, p. 348-349.

Lobo-AraúJo LW, Toledo MTF, EFE MA, Malhado ACM, Vital MVC, TOledo-Lima GS, Macario P, SANTOS JG DOS AND LADLE RJ. 2013. Bird communities in three forest types in the Pernambuco Centre of Endemism, Alagoas, Brazil. Iheringia, Ser Zool 103: 85-96.

LOURES-RIBEIRO A AND ANJOS L Dos. 2006. Falconiformes assemblages in a fragmented landscape of the Atlantic Forest in southern Brazil. Braz Arch Biol Technol 49: 149-162. 
LyRA-NEVES RM DE, DIAS MM, AZEVEDO-JÚNIOR SM DE, TELINO-JÚNIOR WR AND LARRAZÁBAL MEL DE. 2004. Comunidade de aves da Reserva Estadual de Gurjaú, Pernambuco, Brasil. Rev Bras Zool 21: 581-592.

MENEZES AF. 2010. Cobertura vegetal do estado de Alagoas \& mangues de Alagoas. Maceió: Instituto do Meio Ambiente de Alagoas \& Petrobras, 202 p.

Menezes AF, Cavalcante AT And Auto PCC. 2004. A Reserva da Biosfera da Mata Atlântica no Estado de Alagoas, no. 29. São Paulo: Conselho Nacional da Reserva da Biosfera da Mata Atlântica, 56 p.

MMA. 2008. Livro Vermelho da Fauna Brasileira Ameaçada de Extinção. Brasília: Ministério do Meio Ambiente, 1420 p.

MoOJen J, CARVAlHo JC DE AND LOPES H DE S. 1941. Observações sobre o conteúdo gástrico das aves brasileiras. Mem Inst Oswaldo Cruz 36: 405-444.

MOTTA-JÚNIOR JC. 1990. Estrutura trófica e composição das avifaunas de três habitats terrestres na região central do estado de São Paulo. Ararajuba 1: 65-71.

MOURAFBP. 2006. Conceito, importância e principais ameaças à Mata Atlântica Brasileira. In: MOURA FBP (Org), A Mata Atlântica em Alagoas, Maceió: Edufal, Maceió, p. 7-17.

NAKA LN, Rodrigues M, Roos AL And Azevedo MAG. 2002. Bird conservation on Santa Catarina Island, Southern Brazil. Bird Conserv Int 12: 123-150.

Olmos F, Silva WA De G AND Albano CG. 2005. Aves em oito áreas de Caatinga no sul do Ceará e oeste de Pernambuco, nordeste do Brasil: composição, riqueza e similaridade. Pap Avuls Zool 45: 179-199.

PACHECO JF. 2004. As aves da Caatinga - uma análise histórica do conhecimento. In: SILVA JMC ET AL. (Orgs), Biodiversidade da Caatinga: áreas e ações prioritárias para a conservação, Brasília: MMA/UFPE, Brasília, p. 189-250.

PARKER III TA, STOTZ DF AND FITZPATRICK JW. 1996. Ecological and distributional databases. In: STOTZ DF ET AL. (Eds), Neotropical birds: ecology and conservation, Chicago: Univ. Chicago Press, Chicago, p. 113-436.

Primack RB AND Rodrigues E. 2001. Biologia da Conservação, Londrina: PLANTA, 328 p.

REYNAUD PA AND THIOULOUSE J. 2000. Identification of birds as biological markers along a neotropical urbanrural gradient (Cayenne, French Guiana), using co-inertia analysis. J Environ Manage 59: 121-140.

Ribeiro MC, MetzGer JP, MARTENSEN AC, Ponzoni FJ AND Hirota MM. 2009. The Brazilian Atlantic Forest: How much is left, and how is the remaining forest distributed? Implications for conservation. Biol Conserv 142: 1141-1153.

RiBON R. 2010. Amostragem de aves pelo método de listas de Mackinnon. In: VON MATTER S ET AL. (Orgs), Ornitologia e conservação: ciência aplicada, técnicas de pesquisa e levantamento, Rio de Janeiro: Technical Books Editora, Rio de Janeiro, p. 31-44.

RodA SA. 2006. Aves. In: PÔRTO KC ET AL. (Eds), Diversidade Biológica e Conservação da Floresta Atlântica ao Norte do Rio São Francisco, Brasília: Ministério do Meio Ambiente, Brasília, p. 278-299.
Rodrigues RC, ARAujo HFP, LyRA-Neves RM, TelinoJÚNIOR WR AND BOTELHO MCN. 2007. Caracterização da avifauna na Área de Proteção Ambiental de Guadalupe, Pernambuco. Ornithologia 2: 47-61.

RUSCHI A. 1982. Beija-flores do Estado do Espírito Santo, São Paulo: Editora Rios, 264 p.

SCHERER A, Scherer SB, BugOni L, MOHr LV, EFE MA AND HARTZ SM. 2005. Estrutura trófica da avifauna em oito parques da cidade de Porto Alegre, Rio Grande do Sul, Brasil. Ornithologia 1: 25-32.

SICK H. 1997. Ornitologia Brasileira, Rio de Janeiro: Nova Fronteira, $912 \mathrm{p}$.

Silva JMC AND TABARELli M. 2000. Tree species impoverishment and the future flora of the Atlantic Forest of northeast Brazil. Nature 404: 72-74.

Silveira LF, Olmos F AND LONG AJ. 2003a. Birds in Atlantic Forest fragments in north-east Brazil. Cotinga 20: 32-46.

Silveira LF, Olmos F, RodA SA AND LONG AJ. 2003b. Notes on the Seven-coloured Tanager Tangara fastuosa in northeast Brazil. Cotinga 20: 82-88.

Silveira LF AND Straube FC. 2008. Aves Ameaçadas de Extinção no Brasil. In: MACHADO ABM ET AL. (Eds), Livro Vermelho da Fauna Brasileira Ameaçada de Extinção, Volume II, Brasília: Ministério do Meio Ambiente, Brasília, p. 378-679.

SODHI NS, ŞEKERCIOĞLU ÇH, BARLOW J AND ROBINSON SK. 2011. Conservation of Tropical Birds, West Sussex: Wiley-Blackwell, 300 p.

STOUFFER PC AND BIERREGAARD JR RO. 1995. Use of amazonian forest fragments by understory insectivorous birds. Ecology 76: 2429-2445.

StRAUBE FC AND BIANCONI GV. 2002. Sobre a grandeza e a unidade utilizada para estimar o esforço de captura com utilização de redes-de-neblina. Chiroptera Neotropical 8: $150-152$.

TEIXEIRA DM. 1985. The avifauna of the northeastern Brazilian Atlantic forests: a case of mass extinction? Ibis 128: 167-168.

TELINO-JÚNIOR WR, DIAS MM, AZEVEDO-JÚNIOR SM, LYRANEVES RM AND LARRAZÁBAL MEL. 2005. Estrutura trófica da avifauna na Reserva Estadual do Gurjaú, Zona da Mata Sul, Pernambuco, Brasil. Rev Bras Zool 22: 962-973.

VELoso HP. 1992. Sistema Fitogeográfico. In: CASEMIRO AM AND COSTA CHP (Eds), Manual Técnico da Vegetação Brasileira - Série Manuais Técnicos em Geociências, no. 1, Rio de Janeiro: Instituto Brasileiro de Geografia e Estatística - IBGE, Rio de Janeiro, p. 9-38.

VERNER J. 1981. Measuring responses of avian communities to habitat manipulation. Stud Avian Biol, p. 543-547.

WILLIS EO. 1979. The composition of avian communities in remanescent woodlots in southern Brazil. Pap Avuls Zool 33: $1-25$. 


\section{APPENDIX}

Bird species registered at Fazenda Santa Fé, municipality of Tanque d' Area, state of Alagoas, during the sampling period - Nov/2008 to Oct/2009.

\begin{tabular}{|c|c|c|c|c|}
\hline Taxa & Environment $^{1}$ & Frequency $(\%)$ & Feeding habits $^{2}$ & Record $^{3}$ \\
\hline \multicolumn{5}{|l|}{ Tinamiformes } \\
\hline \multicolumn{5}{|l|}{ Tinamidae } \\
\hline Rhynchotus rufescens & $\mathrm{OE}$ & 33.3 & ONI & $\mathrm{V}, \mathrm{S}$ \\
\hline \multicolumn{5}{|l|}{ Galliformes } \\
\hline \multicolumn{5}{|l|}{ Cracidae } \\
\hline Ortalis guttata & FO & 16.7 & FRU & $\mathrm{V}, \mathrm{S}$ \\
\hline \multicolumn{5}{|l|}{ Pelecaniformes } \\
\hline \multicolumn{5}{|l|}{ Ardeidae } \\
\hline Tigrisoma lineatum & $\mathrm{OE}$ & 16.7 & PIS & $\mathrm{V}$ \\
\hline Butorides striata & $\mathrm{OE}$ & 16.7 & PIS & $\mathrm{V}$ \\
\hline Bubulcus ibis & $\mathrm{OE}$ & 25.0 & INS & $\mathrm{V}$ \\
\hline Ardea alba & $\mathrm{OE}$ & 8.3 & PIS & $\mathrm{V}$ \\
\hline \multicolumn{5}{|l|}{ Cathartiformes } \\
\hline \multicolumn{5}{|l|}{ Cathartidae } \\
\hline Cathartes aura & $\mathrm{OE}$ & 58.3 & DET & $\mathrm{V}$ \\
\hline Cathartes burrovianus & $\mathrm{OE}$ & 25.0 & DET & $\mathrm{V}$ \\
\hline Coragyps atratus & $\mathrm{OE}$ & 75.0 & DET & $\mathrm{V}$ \\
\hline \multicolumn{5}{|l|}{ Accipitriformes } \\
\hline \multicolumn{5}{|l|}{ Accipitridae } \\
\hline Rupornis magnirostris & $\mathrm{OE}$ & 75.0 & CAR & $\mathrm{V}, \mathrm{S}$ \\
\hline Geranoaetus albicaudatus & $\mathrm{OE}$ & 25.0 & CAR & $\mathrm{V}$ \\
\hline \multicolumn{5}{|l|}{ Falconiformes } \\
\hline \multicolumn{5}{|l|}{ Falconidae } \\
\hline Caracara plancus & $\mathrm{OE}$ & 41.7 & CAR & $\mathrm{V}, \mathrm{S}$ \\
\hline Milvago chimachima & OE & 41.7 & CAR & $\mathrm{V}, \mathrm{S}$ \\
\hline Herpetotheres cachinnans & FO & 8.3 & CAR & $\mathrm{V}$ \\
\hline \multicolumn{5}{|l|}{ Gruiformes } \\
\hline \multicolumn{5}{|l|}{ Rallidae } \\
\hline Aramides cajanea & FO & 33.3 & ONI & $\mathrm{V}$ \\
\hline Pardirallus nigricans & $\mathrm{OE}$ & 25.0 & ONI & $\mathrm{V}$ \\
\hline \multicolumn{5}{|l|}{ Charadriiformes } \\
\hline \multicolumn{5}{|l|}{ Charadriidae } \\
\hline Vanellus chilensis & $\mathrm{OE}$ & 25.0 & ONI & $\mathrm{V}, \mathrm{S}$ \\
\hline \multicolumn{5}{|l|}{ Jacanidae } \\
\hline Jacana jacana & $\mathrm{OE}$ & 25.0 & ONI & $\mathrm{V}, \mathrm{S}$ \\
\hline \multicolumn{5}{|l|}{ Columbiformes } \\
\hline \multicolumn{5}{|l|}{ Columbidae } \\
\hline Columbina talpacoti & $\mathrm{OE}$ & 66.7 & GRA & $\mathrm{V}, \mathrm{S}, \mathrm{CP}$ \\
\hline Columbina squammata* & $\mathrm{OE}$ & - & ONI & $\mathrm{V}, \mathrm{S}, \mathrm{CP}$ \\
\hline Leptotila verreauxi & $\mathrm{OE}, \mathrm{FO}$ & 25.0 & GRA & $\mathrm{V}, \mathrm{S}, \mathrm{CP}$ \\
\hline \multicolumn{5}{|l|}{ Psittaciformes } \\
\hline \multicolumn{5}{|l|}{ Psittacidae } \\
\hline Diopsittaca nobilis & $\mathrm{OE}, \mathrm{FO}$ & 25.0 & FRU & $\mathrm{V}, \mathrm{S}$ \\
\hline Forpus xanthopterygius & $\mathrm{OE}$ & 66.7 & FRU & $\mathrm{V}, \mathrm{S}$ \\
\hline \multicolumn{5}{|l|}{ Cuculiformes } \\
\hline \multicolumn{5}{|l|}{$\begin{array}{l}\text { Cuculidae } \\
\text { Cuculinae }\end{array}$} \\
\hline Piaya cayana & $\mathrm{OE}, \mathrm{FO}$ & 25.0 & INS & $\mathrm{V}, \mathrm{S}$ \\
\hline
\end{tabular}


APPENDIX (continuation)

\begin{tabular}{|c|c|c|c|c|}
\hline Taxa & Environment $^{1}$ & Frequency (\%) & Feeding habits $^{2}$ & Record $^{3}$ \\
\hline \multicolumn{5}{|l|}{ Crotophaginae } \\
\hline Crotophaga ani & $\mathrm{OE}$ & 25.0 & INS & $\mathrm{V}, \mathrm{S}$ \\
\hline Guira guira & $\mathrm{OE}$ & 50.0 & INS & $\mathrm{V}, \mathrm{S}$ \\
\hline \multicolumn{5}{|l|}{ Taperinae } \\
\hline Tapera naevia & FO & 8.3 & INS & V \\
\hline \multicolumn{5}{|l|}{ Strigiformes } \\
\hline \multicolumn{5}{|l|}{ Tytonidae } \\
\hline Tyto Alba & $\mathrm{OE}$ & 8.3 & CAR & $\mathrm{V}$ \\
\hline \multicolumn{5}{|l|}{ Strigidae } \\
\hline Megascops choliba & $\mathrm{OE}, \mathrm{FO}$ & 25.0 & CAR & $\mathrm{V}, \mathrm{S}$ \\
\hline Pulsatrix perspicillata & $\mathrm{OE}, \mathrm{FO}$ & 8.3 & CAR & $\mathrm{V}$ \\
\hline Athene cunicularia & $\mathrm{OE}$ & 16.7 & CAR & $\mathrm{V}, \mathrm{S}$ \\
\hline \multicolumn{5}{|l|}{ Caprimulgiformes } \\
\hline \multicolumn{5}{|l|}{ Nyctibiidae } \\
\hline Nyctibius griseus & $\mathrm{OE}$ & 41.7 & INS & $\mathrm{V}$ \\
\hline \multicolumn{5}{|l|}{ Caprimulgidae } \\
\hline Antrostomus rufus & $\mathrm{OE}$ & 16.7 & INS & $\mathrm{V}$ \\
\hline Hydropsalis albicollis & $\mathrm{OE}$ & 50.0 & INS & $\mathrm{V}, \mathrm{S}$ \\
\hline Hydropsalis hirundinacea & $\mathrm{OE}$ & 8.3 & INS & $\mathrm{V}$ \\
\hline \multicolumn{5}{|l|}{ Apodiformes } \\
\hline \multicolumn{5}{|l|}{ Trochilidae } \\
\hline \multicolumn{5}{|l|}{ Phaethornithinae } \\
\hline Phaethornis pretrei & $\mathrm{OE}, \mathrm{FO}$ & 33.3 & NEC & $\mathrm{V}, \mathrm{S}$ \\
\hline \multicolumn{5}{|l|}{ Trochilinae } \\
\hline Eupetomena macroura & $\mathrm{OE}$ & 16.7 & NEC & $\mathrm{V}, \mathrm{S}, \mathrm{CP}$ \\
\hline Anthracothorax nigricollis & $\mathrm{OE}$ & 8.3 & NEC & V \\
\hline Chrysolampis mosquitus & $\mathrm{OE}$ & 16.7 & NEC & $\mathrm{V}$ \\
\hline Chlorostilbon notatus & $\mathrm{OE}$ & 8.3 & NEC & $\mathrm{V}$ \\
\hline Chlorostilbon lucidus & $\mathrm{OE}$ & 50.0 & NEC & $\mathrm{V}$ \\
\hline Amazilia fimbriata & $\mathrm{OE}$ & 33.3 & NEC & $\mathrm{V}$ \\
\hline \multicolumn{5}{|l|}{ Coraciiformes } \\
\hline \multicolumn{5}{|l|}{ Alcedinidae } \\
\hline Megaceryle torquata & $\mathrm{OE}$ & 8.3 & PIS & $\mathrm{V}$ \\
\hline Chloroceryle americana & $\mathrm{OE}$ & 8.3 & PIS & $\mathrm{V}$ \\
\hline \multicolumn{5}{|l|}{ Galbuliformes } \\
\hline \multicolumn{5}{|l|}{ Galbulidae } \\
\hline Galbula ruficauda & FO & 25.0 & INS & $\mathrm{V}, \mathrm{S}, \mathrm{CP}$ \\
\hline \multicolumn{5}{|l|}{ Piciformes } \\
\hline \multicolumn{5}{|l|}{ Picidae } \\
\hline Picumnus fulvescens & $\mathrm{OE}, \mathrm{FO}$ & 58.3 & INS & $\mathrm{V}, \mathrm{S}, \mathrm{CP}$ \\
\hline Veniliornis passerinus & $\mathrm{OE}, \mathrm{FO}$ & 25.0 & INS & $\mathrm{V}, \mathrm{S}$ \\
\hline \multicolumn{5}{|l|}{ Passeriformes } \\
\hline \multicolumn{5}{|l|}{ Thamnophilidae } \\
\hline \multicolumn{5}{|l|}{ Thamnophilinae } \\
\hline Formicivora grisea & FO & 25.0 & INS & $\mathrm{V}, \mathrm{S}$ \\
\hline Herpsilochmus atricapillus & FO & 41.7 & INS & $\mathrm{V}, \mathrm{S}$ \\
\hline Taraba major & FO & 41.7 & INS & $\mathrm{V}, \mathrm{S}$ \\
\hline Dendrocolaptidae & & & & \\
\hline Sittasominae & & & & \\
\hline Sittasomus griseicapillus & FO & 8.3 & INS & V \\
\hline
\end{tabular}


APPENDIX (continuation)

\begin{tabular}{|c|c|c|c|c|}
\hline Taxa & Environment $^{1}$ & Frequency $(\%)$ & Feeding habits $^{2}$ & Record $^{3}$ \\
\hline \multicolumn{5}{|l|}{ Dendrocolaptinae } \\
\hline Dendroplex picus & OE, FO & 58.3 & INS & $\mathrm{V}, \mathrm{S}$ \\
\hline \multicolumn{5}{|l|}{ Furnariidae } \\
\hline \multicolumn{5}{|l|}{ Furnariinae } \\
\hline Furnarius leucopus & OE, FO & 50.0 & INS & $\mathrm{V}, \mathrm{S}, \mathrm{CP}$ \\
\hline \multicolumn{5}{|l|}{ Synallaxinae } \\
\hline Phacellodomus rufifrons & $\mathrm{OE}$ & 58.3 & INS & $\mathrm{V}, \mathrm{S}, \mathrm{CP}$ \\
\hline Synallaxis frontalis & $\mathrm{OE}, \mathrm{FO}$ & 58.3 & INS & V, S \\
\hline Synallaxis scutata & FO & 66.7 & INS & $\mathrm{V}, \mathrm{S}, \mathrm{CP}$ \\
\hline \multicolumn{5}{|l|}{ Pipridae } \\
\hline \multicolumn{5}{|l|}{ Neopelminae } \\
\hline Neopelma pallescens & FO & 8.3 & ONI & V \\
\hline \multicolumn{5}{|l|}{ Piprinae } \\
\hline Manacus manacus & FO & 8.3 & FRU & $\mathrm{V}, \mathrm{S}$ \\
\hline \multicolumn{5}{|l|}{ Tityridae } \\
\hline \multicolumn{5}{|l|}{ Tityrinae } \\
\hline Pachyramphus viridis & $\mathrm{OE}$ & 50.0 & INS & $\mathrm{V}, \mathrm{S}, \mathrm{CP}$ \\
\hline Pachyramphus polychopterus & $\mathrm{OE}, \mathrm{FO}$ & 41.7 & INS & $\mathrm{V}, \mathrm{S}, \mathrm{CP}$ \\
\hline \multicolumn{5}{|l|}{ Rhynchocyclidae } \\
\hline \multicolumn{5}{|l|}{ Pipromorphinae } \\
\hline Leptopogon amaurocephalus & FO & 8.3 & INS & $\mathrm{CP}$ \\
\hline \multicolumn{5}{|l|}{ Rhynchocyclinae } \\
\hline Tolmomyias flaviventris & FO & 50.0 & INS & $\mathrm{V}, \mathrm{S}, \mathrm{CP}$ \\
\hline \multicolumn{5}{|l|}{ Todirostrinae } \\
\hline Todirostrum cinereum & $\mathrm{OE}$ & 75.0 & INS & $\mathrm{V}, \mathrm{S}$ \\
\hline Poecilotriccus plumbeiceps & FO & 25.0 & INS & V \\
\hline Hemitriccus margaritaceiventer & FO & 25.0 & INS & $\mathrm{V}, \mathrm{S}$ \\
\hline \multicolumn{5}{|l|}{ Tyrannidae } \\
\hline \multicolumn{5}{|l|}{ Hirundineinae } \\
\hline Hirundinea ferruginea & $\mathrm{OE}$ & 8.3 & INS & V \\
\hline \multicolumn{5}{|l|}{ Elaeniinae } \\
\hline Euscarthmus meloryphus & $\mathrm{OE}$ & 16.7 & INS & V \\
\hline Camptostoma obsoletum & $\mathrm{OE}$ & 41.7 & INS & $\mathrm{V}, \mathrm{S}, \mathrm{CP}$ \\
\hline Elaenia flavogaster & $\mathrm{OE}$ & 41.7 & ONI & $\mathrm{V}, \mathrm{S}, \mathrm{CP}$ \\
\hline Myiopagis caniceps & OE, FO & 58.3 & INS & $\mathrm{V}, \mathrm{S}$ \\
\hline Capsiempis flaveola & $\mathrm{OE}, \mathrm{FO}$ & 16.7 & INS & $\mathrm{V}, \mathrm{S}$ \\
\hline Phyllomyias fasciatus & $\mathrm{OE}$ & 25.0 & INS & $\mathrm{V}, \mathrm{S}$ \\
\hline \multicolumn{5}{|l|}{ Tyranninae } \\
\hline Myiarchus ferox & FO & 16.7 & INS & $\mathrm{V}, \mathrm{S}, \mathrm{CP}$ \\
\hline Pitangus sulphuratus & $\mathrm{OE}$ & 50.0 & ONI & V, S \\
\hline Machetornis rixosa & $\mathrm{OE}$ & 16.7 & INS & $\mathrm{V}$ \\
\hline Megarynchus pitangua & $\mathrm{OE}$ & 41.7 & ONI & $\mathrm{V}, \mathrm{S}, \mathrm{CP}$ \\
\hline Myiozetetes similis & $\mathrm{OE}$ & 41.7 & ONI & V, S \\
\hline \multicolumn{5}{|l|}{ Tyranninae } \\
\hline Tyrannus melancholicus & $\mathrm{OE}$ & 66.7 & INS & $\mathrm{V}, \mathrm{S}, \mathrm{CP}$ \\
\hline \multicolumn{5}{|l|}{ Fluvicolinae } \\
\hline Fluvicola nengeta & $\mathrm{OE}$ & 58.3 & INS & $\mathrm{V}, \mathrm{S}$ \\
\hline Arundinicola leucocephala & $\mathrm{OE}$ & 8.3 & INS & $\mathrm{V}$ \\
\hline \multicolumn{5}{|l|}{ Vireonidae } \\
\hline Cyclarhis gujanensis & $\mathrm{OE}, \mathrm{FO}$ & 75.0 & INS & $\mathrm{V}, \mathrm{S}$ \\
\hline Vireo olivaceus & $\mathrm{FO}$ & 25.0 & INS & $\mathrm{V}, \mathrm{S}, \mathrm{CP}$ \\
\hline
\end{tabular}


APPENDIX (continuation)

\begin{tabular}{|c|c|c|c|c|}
\hline Taxa & Environment $^{1}$ & Frequency (\%) & Feeding habits $^{2}$ & Record $^{3}$ \\
\hline \multicolumn{5}{|l|}{ Vireonidae } \\
\hline Hylophilus amaurocephalus & FO & 41.7 & INS & $\mathrm{V}$ \\
\hline \multicolumn{5}{|l|}{ Troglodytidae } \\
\hline Troglodytes musculus & $\mathrm{OE}, \mathrm{FO}$ & 41.7 & INS & $\mathrm{V}, \mathrm{S}$ \\
\hline Cantorchilus longirostris & FO & 33.3 & INS & $\mathrm{V}, \mathrm{S}$ \\
\hline \multicolumn{5}{|l|}{ Polioptilidae } \\
\hline Polioptila plumbea & $\mathrm{OE}, \mathrm{FO}$ & 91.7 & INS & $\mathrm{V}, \mathrm{S}, \mathrm{CP}$ \\
\hline \multicolumn{5}{|l|}{ Turdidae } \\
\hline Turdus rufiventris & FO & 8.3 & ONI & V \\
\hline Turdus leucomelas & $\mathrm{OE}, \mathrm{FO}$ & 33.3 & ONI & $\mathrm{V}, \mathrm{S}, \mathrm{CP}$ \\
\hline \multicolumn{5}{|l|}{ Motacillidae } \\
\hline Anthus lutescens & $\mathrm{OE}$ & 16.7 & ONI & $\mathrm{V}, \mathrm{S}$ \\
\hline \multicolumn{5}{|l|}{ Coerebidae } \\
\hline Coereba flaveola & $\mathrm{OE}, \mathrm{FO}$ & 83.3 & NEC & $\mathrm{V}, \mathrm{S}, \mathrm{CP}$ \\
\hline \multicolumn{5}{|l|}{ Thraupidae } \\
\hline Nemosia pileata & $\mathrm{OE}, \mathrm{FO}$ & 66.7 & ONI & $\mathrm{V}, \mathrm{S}, \mathrm{CP}$ \\
\hline Thlypopsis sordida & $\mathrm{OE}, \mathrm{FO}$ & 16.7 & ONI & $\mathrm{V}, \mathrm{S}$ \\
\hline Tachyphonus rufus & FO & 16.7 & ONI & $\mathrm{V}$ \\
\hline \multicolumn{5}{|l|}{ Thraupidae } \\
\hline Tangara fastuosa & $\mathrm{OE}$ & 50.0 & FRU & V \\
\hline Tangara sayaca & $\mathrm{OE}$ & 100.0 & ONI & $\mathrm{V}, \mathrm{S}, \mathrm{CP}$ \\
\hline Tangara palmarum & $\mathrm{OE}, \mathrm{FO}$ & 75.0 & ONI & $\mathrm{V}, \mathrm{S}$ \\
\hline Tangara cayana & $\mathrm{OE}, \mathrm{FO}$ & 100.0 & ONI & $\mathrm{V}, \mathrm{S}, \mathrm{CP}$ \\
\hline Paroaria dominicana* & $\mathrm{OE}$ & - & GRA & $\mathrm{V}, \mathrm{S}, \mathrm{CP}$ \\
\hline Dacnis cayana & OE, FO & 25.0 & ONI & $\mathrm{V}, \mathrm{S}$ \\
\hline Hemithraupis guira & $\mathrm{OE}, \mathrm{FO}$ & 58.3 & ONI & $\mathrm{V}, \mathrm{S}$ \\
\hline Conirostrum speciosum & $\mathrm{OE}$ & 33.3 & ONI & $\mathrm{V}, \mathrm{S}$ \\
\hline \multicolumn{5}{|l|}{ Emberizidae } \\
\hline Ammodramus humeralis & $\mathrm{OE}$ & 8.3 & GRA & V \\
\hline Sicalis flaveola* & $\mathrm{OE}$ & - & GRA & $\mathrm{V}, \mathrm{S}, \mathrm{CP}$ \\
\hline Emberizoides herbicola & $\mathrm{OE}$ & 8.3 & GRA & $\mathrm{V}, \mathrm{S}$ \\
\hline Sporophila albogularis & $\mathrm{OE}$ & 25.0 & GRA & V \\
\hline Arremon taciturnus & FO & 58.3 & ONI & $\mathrm{V}, \mathrm{S}, \mathrm{CP}$ \\
\hline \multicolumn{5}{|l|}{ Cardinalidae } \\
\hline Piranga flava** & $\mathrm{OE}$ & - & ONI & - \\
\hline \multicolumn{5}{|l|}{ Parulidae } \\
\hline Basileuterus culicivorus & FO & 66.7 & INS & $\mathrm{V}, \mathrm{S}, \mathrm{CP}$ \\
\hline Basileuterus flaveolus & FO & 66.7 & INS & $\mathrm{V}, \mathrm{S}$ \\
\hline \multicolumn{5}{|l|}{ Fringillidae } \\
\hline Euphonia chlorotica & $\mathrm{OE}$ & 33.3 & ONI & $\mathrm{V}, \mathrm{S}$ \\
\hline Euphonia violacea & OE, FO & 25.0 & FRU & $\mathrm{V}, \mathrm{S}$ \\
\hline \multicolumn{5}{|l|}{ Passeridae } \\
\hline Passer domesticus & $\mathrm{OE}$ & 25.0 & ONI & V \\
\hline
\end{tabular}

${ }^{1}$ Environment: (OE) open environments, such as pasture and orchard; (FO) forested areas.

${ }^{2}$ Feeding habits: (ONI) omnivore, (FRU) frugivore, (PIS) piscivore, (INS) insectivore, (DET) detritivore, (CAR) carnivore, (GRA) granivore and (NEC) nectarivore; according Moojen et al. (1941), Motta-Junior (1990), Sick (1997) and Telino-Júnior (2005).

${ }^{3}$ Record: (V) visual, (S) sound and (CP) captured.

*Species that were being released into the wild at the reserves.

**Species recorded occasionally between samples. 
